\title{
PENGARUH MODEL GUIDED DISCOVERY LEARNING DENGAN METODE EKSPERIMEN TERHADAP HASIL BELAJAR FISIKA PESERTA DIDIK MAN 1 MATARAM DITINJAU DARI GAYA BELAJAR VAK
}

\author{
Suci Febriani*, Muhammad Taufik, Ni Nyoman Sri Putu Verawati \\ Program Studi Pendidikan Fisika, Universitas Mataram \\ *Email: suciifeb@gmail.com
}

DOI: http://dx.doi.org/10.29303/jpft.v5i1.872

\begin{abstract}
The aim of this research applied a quasi-experiment by factorial design $2 \times 3$ which was conducted to the student of MAN 1 Mataram is to find out the influence of guided discovery learning model combined with experiment method and VAK style due to physics learning outcomes. The population is the students from grade X MIA in MAN 1 Mataram. The sampling technique is using purposive sampling, where, grade X of MIA 1 as an experiment class and grade X of MIA 2 as a control. Data for learning outcomes are measured by applying multiple choice test while learning style of students using a questionnaire - the hypothesis test using ANAVA test of two ways supported by SPSS 16 with $5 \%$ significance level. According to the analysis results, it can be concluded that: 1) there is an effect of guided discovery learning model with experimental method toward physics learning outcome of students because of sig. $<0,05 ; 2)$ there is no effect of VAK learning style on physics learning result in MAN students because sig. $>0,05 ; 3)$ there is no interaction between guided discovery learning model with experiment and VAK learning style method of physics learning result in MAN student because of sig. $>0,05$.
\end{abstract}

Keywords: Guided Discovery Learning, Experiment Method, VAK Learning Style

\section{PENDAHULUAN}

Fisika merupakan mata pelajaran yang mempelajari tentang suatu sifat dan gejala-gejala alam. Selain itu mata pelajaran fisika juga sangat berkaitan dengan kehidupan kita sehari-hari, untuk peserta didik pentingnya mempelajari mata pelajaran fisika antara lain membantu peserta didik dalam memecahkan masalah yang ada pada kehidupan sehari-hari yang berkaitan dengan fisika, mampu membuktikan suatu teori atau konsep yang telah ada sebelumnya, dapat meningkatkan kemampuan berpikir kritis, menjadikan peserta didik yang aktif, kreatif, dan inovatif, serta dapat meningkatkan hasil belajar peserta didik.

Pada proses pembelajaran fisika guru harus lebih efektif dalam memilih model dan metode pembelajaran agar dapat terjadi komunikasi yang baik antara peserta didik dengan peserta didik dan guru dengan peserta didik. Model dan metode dalam pembelajaran fisika berfungsi untuk mempermudah guru dalam mengajar peserta didik agar peserta didik mudah memahami materi yang disampaikan, sehingga diharapakan dapat meningkatkan hasil belajar peserta didik.

Berdasarkan hasil observasi yang dilakukan di MAN 1 Mataram melalui wawancara dengan guru mata pelajaran fisika dan beberapa peserta didik, menunjukkan bahwa proses pembelajaran masih dilakukan secara konvensional, dimana pada saat pembelajaran berlangsung masih berpusat pada guru (teaching center). Permasalahan lainnya yang dapat dijumpai pada saat pembelajaran disekolah yaitu kurangnya memperhatikan aspek gaya belajar dari peserta didik. Hal ini yang dapat mempengaruhi hasil belajar peserta didik karena terdapat karakteristik khusus yang membedakan masing-masing peserta didik lainnya berdasarkan gaya belajarnya (Nurmayani et al. 2016).

Berdasarkan permasalahan tersebut maka diperlukan suatu model dan metode 
pembelajaran yang diharapkan meningkatkan hasil belajar peserta didik salah satunya yaitu model pembelajaran guided discovery dengan metode eksperimen yang diharapkan membantu peserta didik dalam proses pembelajaran. Model pembelajaran discovery tipe guided discovery berhasil membantu peserta didik dalam pembelajaran dan proses pembelajaran menjadi menyenangkan sehingga hasil belajar yang dihasilkan maksimal, serta respon peserta didik terhadap penerapan model pembelajaran discovery tipe guided discovery cenderung positif (Saidatunnisa et al. 2017), selain itu dengan metode eksperimen yang diberikan membuat peserta didik lebih aktif belajar dan meningkatkan hasil belajar fisika peserta didik (Wahyuni et al. 2016).

Model discovery learning merupakan sebuah model pengajaran yang bertujuan mengembangkan kemampuan berpikir untuk memecahkan masalah yang berkaitan dengan kehidupan sehari-hari dengan melibatkan peserta didik aktif dalam proses belajar dan meyakinkan bahwa pembelajaran sejati melalui penemuan sendiri (Fitri \& Derlina, 2015).

Terdapat dua tipe dari model discovery learning yaitu guided discovery dan discovery murni. Menurut Shulman dan Keisler dalam Mayer (2014) menyatakan bahwa dalam pembelajaran guided discovery umumnya lebih efektif dari pada discovery murni. Pada kesempatan ini peneliti memilih untuk menggunakan model pembelajaran discovery tipe guided discovery.

Model guided discovery learning lebih efektif dalam pembelajaran fisika, karena model ini membantu peserta didik bertemu dengan dua kriteria penting dalam pembelajaran aktif yaitu membangun pengetahuan untuk membuat pengertian dari informasi baru dan mengintegrasikan informasi baru sampai ditemukan pengetahuan yang tepat (Rohim et al. 2013).
Pada penelitian ini peneliti memilih untuk menerapkan pembelajaran menggunkan fase model guided discovery learning yang telah dipaparkan oleh Eggen \& Kauchak (2016), fase-fase model pembelajaran guided discovery dapat dilihat pada Tabel 1 Fase-fase di dalam menerapkan pembelajaran dengan model guided discovery.

Tabel 1. Fase-fase di dalam menerapkan pembelajaran dengan model guided discovery

\begin{tabular}{|c|c|}
\hline Fase & Deskripsi \\
\hline $\begin{array}{c}\text { Fase 1: } \\
\text { Pendahuluan }\end{array}$ & $\begin{array}{l}\text { Guru berusaha } \\
\text { menarik perhatian } \\
\text { peserta didik dan } \\
\text { menetapkan fokus } \\
\text { pelajaran. }\end{array}$ \\
\hline $\begin{array}{c}\text { Fase 2: Fase } \\
\text { Terbuka }\end{array}$ & $\begin{array}{l}\text { Guru memberi } \\
\text { peserta didik contoh } \\
\text { dan meminta peserta } \\
\text { didik untuk } \\
\text { mengamati dan } \\
\text { membandingkan } \\
\text { contoh-contoh. }\end{array}$ \\
\hline $\begin{array}{c}\text { Fase 3: Fase } \\
\text { Konvergen }\end{array}$ & \begin{tabular}{lr}
\multicolumn{2}{l}{ Guru menanyakan } \\
pertanyaan- \\
pertanyaan lebih \\
spesifik \\
dirancang yang \\
membimbing peserta \\
didik mencapai \\
pemahaman & tentang \\
konsep r & atau \\
generalisasi.
\end{tabular} \\
\hline $\begin{array}{c}\text { Fase 4: Penutup } \\
\text { dan Penerapan }\end{array}$ & $\begin{array}{l}\text { Guru membimbing } \\
\text { peserta didik } \\
\text { memahami definisi } \\
\text { suatu konsep atau } \\
\text { pernyataan } \\
\text { generalisasi dan } \\
\text { peserta } \\
\text { menerapkan didik } \\
\text { pemahaman mereka } \\
\text { ke dalam konteks } \\
\text { baru. }\end{array}$ \\
\hline
\end{tabular}

(Eggen \& Kauchak, 2016)

Berdasarkan sintak model guided discovery learning, metode eksperimen disisipkan pada fase kedua yaitu fase terbuka 
yang bertujuan mendorong keterlibatan peserta didik dalam melakukan suatu proses pembelajaran. Salah satu ciri khas dari pelajaran fisika yaitu banyaknya materi yang dapat dipelajari dengan melakukan suatu eksperimen salah satunya materi mengenai gerak harmonis sederhana sehingga pada proses pembelajaran ini peneliti menggunakan metode eksperimen.

Metode eksperimen pada hakikatnya adalah cara menyampaikan suatu materi pembelajaran dengan melakukan suatu eksperimen, percobaan atau penelitian fisika dengan meniru cara bekerja yang dilakukan oleh para fisikawan (Faizi, 2013).

Metode eksperimen yang diterapkan dalam model guided discovery ini dapat menjadikan proses pembelajaran tidak hanya berpusat kepada guru melainkan peserta didik turut ikut serta dalam melakukan kegiatan pembelajaran yang bertujuan untuk meningkatkan hasil belajar peserta didik secara maksimal.

Hasil belajar yang diperoleh peserta didik merupakan suatu tolak ukur kemampuan peserta didik setelah melakukan suatu kegiatan pembelajaran. Menurut Purwanto dalam Suprayanti, et al. (2016) Hasil belajar dapat dijelaskan dengan memahami dua kata yang membentuknya, yaitu "hasil" dan "belajar". Pengertian hasil (product) menunjukkan pada suatu perolehan akibat dilakukannya suatu aktivitas

Hasil belajar mencakup kedalam 3 ranah yaitu kognitif, afektif dan psikomotor, dalam penelitian ini peneliti meneliti dalam ranah kognitif dimana afektif dan psikomotor sebagai data pendukung. Hasil belajar pada ranah kognitif menggunakan taksonomi bloom yang telah di revisi yaitu $\mathrm{C}_{1}$ sampai $\mathrm{C}_{6}$, yaitu mengingat $\left(\mathrm{C}_{1}\right)$, memahami $\left(\mathrm{C}_{2}\right)$, mengaplikasi $\left(\mathrm{C}_{3}\right)$, menganalisis $\left(\mathrm{C}_{4}\right)$, mengevaluasi $\left(\mathrm{C}_{5}\right)$, dan mencipta $\left(\mathrm{C}_{6}\right)$ (Anderson \& Krathwol, 2015). Hasil belajar pada penelitian ini yaitu hasil belajar dalam ranah kognitif setelah diberikan perlakuan model guided discovery learning dengan metode eksperimen ditinjau dari gaya belajar VAK.

Gaya belajar merupakan cara yang cenderung dipilih seseorang untuk menerima informasi dari lingkungan dan memperoses informasi tersebut (Susilo, 2016). Gaya belajar disini dibagi menjadi tiga jenis yaitu gaya belajar visual, audio, dan kinestetik. Menurut Huda (2016) tiga modalitas pembelajaran yang pertama kali dikembangkan oleh Neil Fleming untuk memprioritaskan individu dalam proses belajarnya yaitu visual, auditoris, dan kinestetik (VAK).

Menurut Suyono dan Hariyanto (2016) ketiga gaya belajar dapat diketahui atau dideteksi dari kebiasaan (habbit) anak ketika belajar, antara lain

Gaya belajar visual

1.) Lebih mudah mengingat apa yang dilihat daripada yang didengar;

2.) Mudah mengingat dengan asosiasi visual;

3.) Pembaca yang cepat dan tekun, memiliki hobi membaca;

4.) Lebih suka membaca sendiri dari pada dibacakan.

Gaya belajar audio

1.) Berbicara kepada diri sendiri saat belajar atau bekerja;

2.) Senang membaca dengan keras dan mendengarkannya;

3.) Berbicara dengan irama terpola;

4.) Biasanya menjadi pembicara yang fasih. Gaya belajar kinestetik

1.) Selalu berorientasi pada fisik dan banyak gerak;

2.) Banyak menggunakan isyarat tubuh;

3.) Menggunkan jari sebagai penunjuk tatkala membaca;

4.) Menghafal dengan cara berjalan dan melihat.

Dari uraian diatas peneliti dapat menyimpulkan bahwa gaya belajar merupakan suatu cara belajar peserta didik dalam menyerap informasi, mengolah 
informasi yang diperoleh dalam proses pembelajaran.

Penelitian ini bertujuan untuk mengetahui: (1) apakah terdapat pengaruh model guided discovery learning dengan metode eksperimen terhadap hasil belajar fisika peserta didik MA?, (2) apakah ada pengaruh gaya belajar VAK terhadap hasil belajar fisika peserta didik MA?, (3) apakah ada interaksi antara model guided discovery learning dengan metode eksperimen dan gaya belajar VAK terhadap hasil belajar fisika peserta didik MA?

\section{METODE PENELITIAN}

Penelitian ini termasuk penelitian kuasi eksperimen yang digunakan untuk mencari pengaruh dari suatu perlakuan yang diberikan dengan pretest-posttest control group design. Desain penelitian menggunakan desain faktorial 2 x 3 yang dapat dilihat pada Tabel 2 sebagai berikut.

Tabel 2. Desain Penelitian Faktorial 2x3

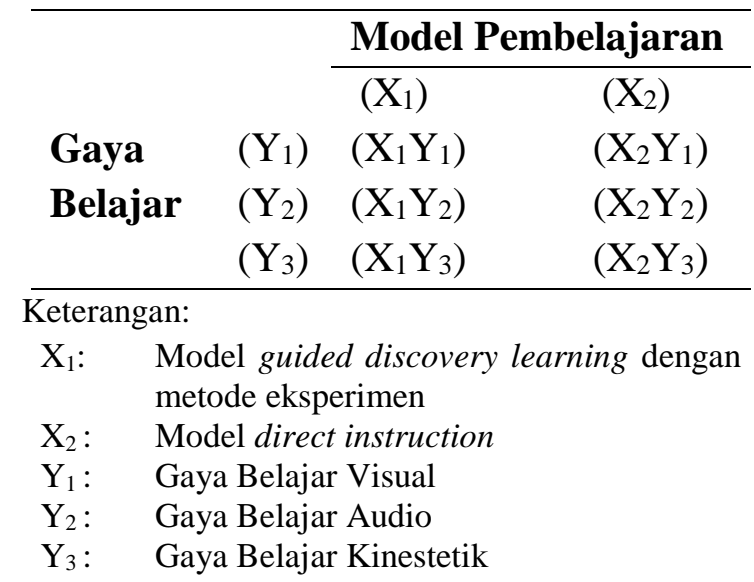

Pada tahap pelaksanaanya sebelum diberikan tes awal peserta didik terlebih dahulu diberikan angket gaya belajar untuk mengetahui karakteristik dari masingmasing peserta didik, selanjutnya kedua kelompok diberikan tes awal untuk mengetahui kemampuan awal dari kedua kelompok kelas. Setelah diberikan tes awal untuk kedua kelompok mendapatkan perlakuan berbeda yaitu untuk kelas eksperimen diberi perlakuan berupa model guided discovery learning dengan metode eksperimen, sedangkan untuk kelas kontrol diberi perlakuan berupa model direct instruction dan diakhiri dengan pemberian tes akhir untuk kedua kelompok sampel.

Teknik pengambilan sampel pada penelitian ini menggunakan purposive sampling dengan sampel peserta didik kelas $\mathrm{X}$ MIA 1 dan MIA 2. Instrumen dalam penelitian ini berupa angket gaya belajar dan tes hasil belajar. Angket gaya belajar digunakan peneliti untuk mengetahui kelompok peserta didik yang memiliki gaya belajar visual, audio, dan kinestetik. Angket gaya belajar dalam hal ini telah diuji validitas oleh dosen ahli. Sedangkan tes hasil belajar berjumlah 25 item soal yang diperoleh dari hasil uji validitas, realibilitas, daya beda, dan tingkat kesukaran. Untuk uji hipotesis menggunakan ANAVA dua jalan berbantuan SPSS 16 dengan taraf signifikan $5 \%$ dengan syarat data terdistribusi normal dan homogen dengan kriteria pengambilan yaitu $\mathrm{H}_{0}$ ditolak jika Sig < 0,05 maka $\mathrm{H}_{\mathrm{a}}$ diterima.

\section{HASIL DAN PEMBAHASAN}

Hasil penelitian berupa data gaya belajar, data tes awal dan data tes akhir peserta didik. Data tes awal peserta didik untuk kelas eksperimen dan kelas kontrol dengan nilai tertinggi adalah sama yaitu 44 dan dan untuk nilai terendah berturut-turut sebesar 8 dan 4, dengan standar deviasi untuk kelas eksperimen dan kelas kontrol berturut-turut sebesar 9,176 dan 9,798. Sedangkan data tes akhir dari kelas eksperimen dan kelas kontrol untuk nilai tertinggi berturut-turut sebesar 88 dan 84 dan untuk nilai terendah berturut-turut sebesar 40 dan 32, dengan standar deviasi untuk kelas eksperimen dan kelas kontrol berturut-turut sebesar 12,049 dan 14,515. Data gaya belajar diperoleh dari pengisian angket oleh peserta didik. Data hasil angket gaya belajar dan rata-rata nilai tes akhir dari masing-masing gaya belajar dapat dilihat 
pada Tabel 3. Selanjutnya untuk hasil analisis uji hipotesis menggunakan ANAVA dua jalan dibantu dengan SPSS 16 dapat dilihat pada Tabel 4.

Tabel 3. Data Hasil Angket Gaya Belajar Peserta Didik

\begin{tabular}{lcc}
\hline & $\begin{array}{c}\text { Kelas } \\
\text { Eksperimen }\end{array}$ & Kelas Kontrol \\
\hline Jumlah Peserta Didik & 31 & 30 \\
Jumlah peserta didik kategori gaya belajar visual & 13 & 9 \\
Jumlah peserta didik kategori gaya belajar audio & 12 & 18 \\
Jumlah peserta didik kategori gaya belajar kinestetik & 6 & 3 \\
Rata-rata nilai gaya belajar visual & 71,1 & 55,1 \\
Rata-rata nilai gaya belajar audio & 61 & 57,3 \\
Rata-rata nilai gaya belajar kinestetik & 58 & 53,3 \\
\hline
\end{tabular}

Tabel 4. Test of Between Subjects Effects

\begin{tabular}{lccccc}
\hline \multicolumn{1}{c}{ Source } & $\begin{array}{c}\text { Type III } \\
\text { Sum of } \\
\text { Squares }\end{array}$ & Df & $\begin{array}{c}\text { Mean } \\
\text { Square }\end{array}$ & F & Sig \\
\hline Corrected Model & $2090,734^{\mathrm{a}}$ & 5 & 418,147 & 2,435 &, 046 \\
Intercept & 153137,059 & 1 & 153137,059 & 891,795 &, 000 \\
Kelas & 714,031 & 1 & 714,031 & 4,158 &, 046 \\
Gaya_belajar & 372,984 & 2 & 186,492 & 1,086 &, 345 \\
Kelas*gaya_belajar & 493,490 & 2 & 246,745 & 1,437 &, 246 \\
Error & 9444,479 & 55 & 171,718 & & \\
Total & 234992,000 & 61 & & & \\
Corrected Total & 11535,213 & 60 & & & \\
\hline
\end{tabular}

Dapat dilihat dari Tabel 3 untuk kelas eksperimen peserta didik yang memiliki gaya belajar visual rata-rata nilai tes akhirnya sebesar 71,1 dimana nilai ini lebih besar dibandingkan kelas kontrol yang memiliki rata-rata nilai sebesar 55,1.

Rata-rata nilai tes akhir gaya belajar audio untuk kelas eksperimen berturut-turut sebesar 61 dan 57,3. Sedangkan rata-rata nilai tes akhir gaya belajar kinestetik untuk kedua kelas memperoleh nilai yang paling rendah dibandingkan dengan rata-rata nilai untuk gaya belajar visual dan audio yaitu 58 dan 53,3.

Berdasarkan Tabel 4 dapat dilihat untuk pengaruh model guided discovery learning terhadap hasil belajar fisika peserta didik diperoleh signifikansi sebesar 0,046, ini berarti nilai $\mathrm{Sig}<0,05$. Jadi, $\mathrm{H}_{01}$ ditolak dan $\mathrm{H}_{\mathrm{a} 1}$ diterima, dimana terdapat pengaruh model guided discovery learning dengan metode eksperimen terhadap hasil belajar fisika peserta didik. Selanjutnya untuk pengaruh gaya belajar VAK terhadap hasil belajar fisika peserta didik diperoleh signifikansi sebesar 0,345, ini berarti nilai Sig> 0,05. Jadi, $\mathrm{H}_{0}$ diterima dan $\mathrm{H}_{\mathrm{a}}$ ditolak, dimana tidak terdapat pengaruh gaya belajar VAK terhadap hasil belajar fisika peserta didik. Sedangkan untuk interaksi antara model guided discovery learning dengan metode eksperimen dan gaya belajar VAK terhadap hasil belajar fisika peserta didik diperoleh signifikansi sebesar 0,246, ini ini berarti nilai $\mathrm{Sig}>0$,05. Jadi, $\mathrm{H}_{0}$ diterima dan $\mathrm{H}_{\mathrm{a}}$ ditolak, dimana tidak terdapat interaksi antara model guided discovery learning dengan metode eksperimen dan gaya belajar VAK terhadap hasil belajar fisika peserta didik.

Tidak adanya interaksi antara model guided discovery learning dengan metode eksperimen dan gaya belajar VAK terhadap hasil belajar fisika peserta didik dapat dilihat 
pada Gambar 1, dimana secara keseluruhan terjadinya interaksi apabila dari ketiga gaya belajar tersebut saling berpotongan. Tidak terjadinya perpotongan antara ketiga gaya belajar tersebut dikarenakan untuk kelas eksperimen dan kelas kontrol memiliki ratarata nilai gaya belajar kinestetik yang samasama rendah sehingga yang berpotongan hanya gaya belajar visual dan audio saja.

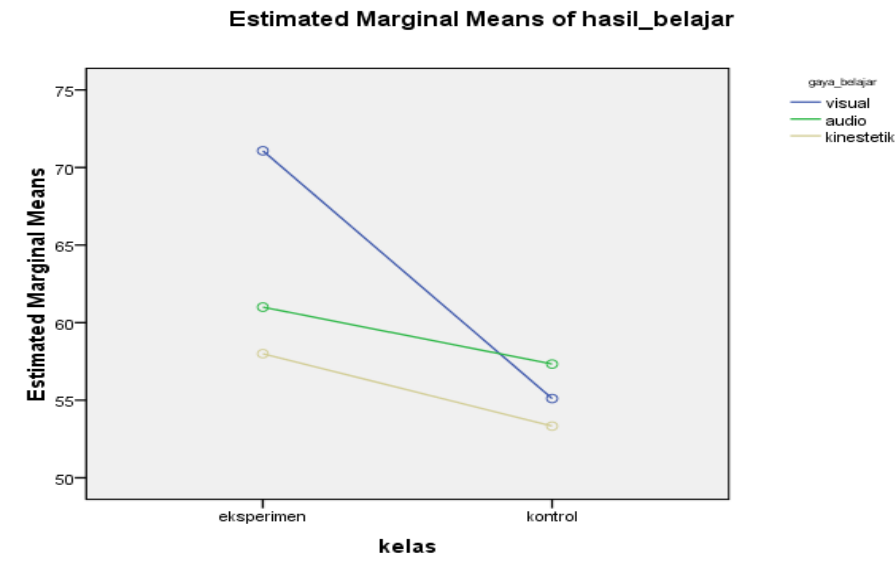

Gambar 1. Interaksi antara model dengan gaya belajar VAK terhadap hasil belajar fisika peserta didik

Pengaruh Model Pembelajaran Guided Discovery dengan Metode Eksperimen Terhadap Hasil Belajar Peserta Didik

Berdasarkan hasil penelitian kedua kelas memiliki nilai rata-rata yang meningkat tetapi pada kelas eksperimen yang diterapkan model guided discovery learning dengen metode eksperimen jauh lebih tinggi dibandingkan dengan kelas kontrol yang diberikan perlakuan dengan model direct instruction melalui pendekatan konvensional. Hasil dari tes akhir kemudian dianalisis dan dilakukan uji hipotesis ANAVA dua jalan dengan berbantuan SPSS 16 diperoleh siginfikan yaitu mencapai 0,046, sehingga nilai $\mathrm{Sig}<0,05$. Hal ini menunjukkan bahwa model guided discovery learning dengan metode eksperimen berpengaruh terhadap hasil belajar fisika peserta didik sehingga $\mathrm{H}_{01}$ ditolak dan $\mathrm{H}_{\mathrm{a} 1}$ diterima. Beberapa penelitan juga mengungkapkan bahwa penerapan discovery learning tebukti secara positif meningkatkan hasil belajar peserta didik (Lidiana et al, 2018; Azizirrahim et al, 2015).

$\begin{array}{rrr}\text { Berdasarkan } & \text { hasil pengamatan } \\ \text { peneliti adanya } & \text { pengaruh model }\end{array}$

pembelajaran terhadap hasil belajar peserta didik dikarenakan fase-fase pada model pembelajaran guided discovery dengan metode eksperimen dapat menjadikan peserta didik lebih terarah dan lebih memahami materi yang sedang diajarkan, hal ini dapat dilihat peneliti pada saat fase ke 2 yaitu fase terbuka dan fase ke 3 yaitu fase konvergen sedang berlangsung.

Penelitian lain juga menunjukkan bahwa penerapan model guided discovery learning dalam proses pembelajaran fisika memberikan pengaruh terhadap tingkat kemampuan kognitif fisika yang dimiliki peserta didik yang lebih baik daripada penggunaan model konvensional (Purnomo et al. 2016). Penelitian lainnya yang mendukung menyatakan bahwa penerapan discovery learning berbantuan media laboratorium virtual berpengaruh terhadap penguasaan konsep fisika siswa (Sari et al, 2016). Penguasaan konsep yang baik tentunya akan menghasilkan kemampuan kognitif yang baik pula, sehingga penggunaan discovery learning menghasilkan siswa dengan hasil belajar yang baik dikarenakan penguasaan konsep siswa menjadi lebih baik. 


\section{Pengaruh Gaya Belajar VAK Terhadap} Hasil Belajar Fisika Peserta Didik

Berdasarkan hasil analisis statistik uji ANAVA dua jalan berbantuan SPSS 16 didapatkan nilai signifikan sebesar 0,345, sehingga nilai Sig $>0,05$. Hal ini menunjukkan bahwa gaya belajar VAK tidak berpengaruh terhadap hasil belajar fisika peserta didik sehingga $\mathrm{H}_{02}$ diterima dan $\mathrm{H}_{\mathrm{a} 2}$ ditolak. Hal ini dapat terjadi ketika melihat nilai dari rata-rata peserta didik juga menunjukkan bahwa tidak hanya tipe gaya belajar visual yang memiliki nilai rata-rata tertinggi, tetapi untuk kelas kontrol nilai rata-rata tertinggi diperoleh dari peserta didik yang memiliki tipe gaya belajar audio dan untuk gaya belajar kinestetik dari masing-masing kelas didapatkan nilai ratarata paling rendah.

Berdasarkan hasil pengamatan peneliti, tidak adanya pengaruh gaya belajar terhadap hasil belajar peserta didik pada saat melakukan diskusi kelompok dalam percobaan dan menjawab soal yang diberikan peneliti dapat terjadi dikarenakan adanya tukar pendapat dari peserta didik yang memiliki gaya belajar visual, audio, dan kinestetik dimana dalam satu kelompok terdiri dari peserta didik yang mempunyai 3 gaya belajar atau 2 gaya belajar, sehingga peserta didik dapat saling membantu dan bertukar pendapat saat melakukan suatu percobaan dan menjawab soal. Hal ini sejalan dengan penelitian lain yang menyatakan bahwa tidak ada pengaruh gaya belajar terhadap prestasi belajar dengan kata lain peserta didik dengan gaya belajar VAK mempunyai prestasi belajar yang sama dikarenakan pada hakikatnya seluruh peserta didik yang mempunyai gaya belajar VAK memiliki kesempatan yang sama dalam hal bertanya dan berpendapat untuk memperdalam pemahaman mereka, sehingga seluruh peserta didik terdapat kemungkinan memiliki pemahaman yang sama (Yannuansa et al. 2015).

Interaksi Model Guided Discovery Learning dengan Metode Eksperimen dan Gaya Belajar VAK Terhadap Hasil Belajar Fisika Peserta Didik

Berdasarkan hasil analisis statistik uji ANAVA dua jalan berbantuan SPSS 16 didapatkan nilai signifikan sebesar 0,246, sehingga nilai Sig> 0,05. Hal ini menunjukkan bahwa tidak terdapat interaksi antara model guided discovery learning dengan metode eksperimen dan gaya belajar VAK terhadap hasil belajar fisika peserta didik.

Gambar 1 yaitu grafik interaksi antara model guided discovery learning dengan metode eksperimen dan gaya belajar VAK terhadap hasil belajar fisika peserta didik secara umum menunjukkan tidak terdapat interaksi ini dikarenakan tidak adanya titik perpotongan antara ketiga gaya belajar tersebut, hanya terdapat titik perpotongan antara gaya belajar visual dan audio saja. Tidak adanya titik perpotangan antara gaya belajar visual, audio dan kinestetik ini dikarenakan nilai rata-rata dari peserta didik kelas eksperimen maupun kelas kontrol pada peserta didik yang memiliki gaya belajar kinestetik keduanya tergolong rendah dibandingkan dengan gaya belajar visual dan audio.

Penelitian lain juga menyatakan bahwa tidak terdapat interaksi antara gaya belajar dan model yang digunakan dalam pembelajaran pada hasil belajar peserta didik dapat dilihat dari gaya belajar kinestetik yang memiliki kemiringan negatif sedangkan gaya belajar lain positif (Gunawan et al. 2016).

Faktor lain yang mengakibatkan tidak terjadinya interaksi antara model pembelajaran dan gaya belajar terhadap hasil belajar fisika peserta didik yaitu model pembelajaran guided discovery dengan 
metode eksperimen yang memberikan kesempatan untuk peserta didik bekerja sama dalam mengambil suatu generalisasi dari hasil diskusi yang mendukung situasi belajar peserta didik menjadi menyenangkan tanpa memunculkan gaya belajar yang terdapat dalam diri masing-masing peserta didik. Hasil penelitian ini didukung oleh hasil penelitian sebelumnya oleh Desstya et al. (2012) yang menyatakan tidak adanya interaksi yang signifikan antara pembelajaran TGT menggunakan media animasi dan kartu, kemampuan memori dan gaya belajar terhadap prestasi belajar peserta didik ranah kognitif, kemungkinan disebabkan dari pembelajaran TGT yang memberi kesempatan peserta didik untuk lebih rileks dan menggembirakan situasi kondusif ini akan lebih mendukung proses pemahaman bagi peserta didik dengan kemampuan memori yang tinggi, meskipun tanpa memunculkan cara belajar yang sudah tertanam pada peserta didik.

\section{PENUTUP}

Berdasarkan hasil penelitian dan pembahasan maka dapat ditarik 3 kesimpulan yaitu, terdapat pengaruh model guided discovery learning dengan metode eksperimen terhadap hasil belajar fisika peserta didik. Kedua, tidak terdapat pengaruh gaya belajar VAK terhadap hasil belajar fisika peserta didik. Ketiga, tidak terdapat interaksi antara model guided discovery learning dengan metode eksperimen dan gaya belajar VAK terhadap hasil belajar fisika peserta didik.

\section{REFERENSI}

Anderson, L.W \& Krathwohl, D.R. 2015. Kerangka Landasan untuk Pembelajaran, Pengajaran, dan Asesmen: Revisi Taksonomi Pendidikan Bloom. Yogyakarta: Pustaka Pelajar.
Azizirrahim, E., Sutrio, S., \& Gunawan, G. 2017. Penerapan Pendekatan Keterampilan Proses Sains dalam Model Pembelajaran Guided Discovery untuk Meningkatkan Hasil Belajar IPA Fisika pada Siswa Kelas VIIA SMPN 8 Mataram Tahun Ajaran 2015/2016. Jurnal Pendidikan Fisika dan Teknologi, 1(4), 272-275.

Desstya, A., \& Saputro, S. 2017. Pembelajaran Kimia Dengan Metode Teams Games Tournaments (TGT) Menggunakan Media Animasi dan Kartu Ditinjau Dari Kemampuan Memori Dan Gaya Belajar Siswa. Universitas Sebelas Maret, 1(3), 177-182.

Eggen, P \& Kauchak, D. 2016. Strategi dan Model Pembelajaran Mengajarkan Konten dan Keterampilan Berpikir Edisi Keenam. Jakarta: PT Indeks.

Faizi, M. 2013. Ragam Metode Mengajarkan Eksakta pada Murid. Yogyakarta: DIVA Press.

Fitri, M., \& Derlina. 2015. Pengaruh Model Pembelajaran Discovery Learning terhadap Hasil Belajar Siswa pada Materi Pokok Suhu dan Kalor. INPAFI (Inovasi Pembelajaran Fisika), 3(2).

Gunawan, Harjono, A., \& Imran, I. 2016. Pengaruh Multimedia Interaktif dan Gaya Belajar Terhadap Penguasaan Konsep Kalor Siswa. Jurnal Pendidikan Fisika Indonesia, 12(2), 118-125.

Huda, M. 2016. Model-Model Pengajaran dan Pembelajaran: Isu-Isu Metodis dan Paradigmatis. Yogyakarta: Pustaka Pelajar.

Lidiana, H., Gunawan, G., \& Taufik, M. 2018. Pengaruh Model Discovery Learning Berbantuan Media PhET Terhadap Hasil Belajar Fisika Peserta Didik Kelas XI SMAN 1 Kediri Tahun Ajaran 2017/2018. Jurnal Pendidikan Fisika dan Teknologi, 4(1), 33-39. 
Mayer, R. E. 2004. Should there be a threestrikes rule against pure discovery learning. American psychologist, 59(1), 14.

Nurmayani, N., Syuaib, M. Z., \& 'Ardhuha, J. 2016. Pengaruh Gaya Belajar VAK pada Penerapan Model Pembelajaran Problem Based Learning Terhadap Hasil Belajar IPA Fisika Siswa SMP Negeri 2 Narmada Tahun Ajaran 2015/2016. Jurnal Pendidikan Fisika dan Teknologi, 2(1), 13-21.

Purnomo, H. Y., Mujasam, M., \& Yusuf, I. 2016. Penerapan Model Guided Discovery Learning Pada Materi Kalor Terhadap Hasil Belajar Kognitif Peserta Didik Kelas VII SMPN 13 Prafi Manokowari Papua Barat. Pancaran Pendidikan, 5(2), 114.

Rohim, F., Susanto, H., \& Ellianawati. 2012. Penerapan Model Discovery Terbimbing Pada Pembelajaran Fisika Untuk Meningkatkan Kemampuan Berpikir Kreatif. Unnes Physics Education Journal, 1(1).

Saidatunnisa, Hamid, A., \& Wahyuni, A. 2017. Penerapan Model Pembelajaran Discovery Tipe Guided Discovery dalam Upaya Meningkatkan Hasil Belajar Fisika Siswa Kelas XI Mipa 2 di Sman 16 Banda Aceh. Jurnal Ilmiah Mahasiswa Pendidikan Fisika, 2(1), 20-29.

Sari, P. I., Gunawan, G., \& Harjono, A. (2016). Penggunaan Discovery Learning Berbantuan Laboratorium Virtual pada Penguasaan Konsep Fisika Siswa. Jurnal Pendidikan Fisika dan Teknologi, 2(4), 176-182.

Suprayanti, I., Ayub, S., \& Rahayu, S. 2016. Penerapan Model Discovery Learning Berbantuan Alat Peraga Sederhana untuk Meningkatkan Aktivitas dan Hasil Belajar Siswa Kelas VII SMPN 5 Jonggat Tahun Pelajaran 2015/2016. Jurnal
Pendidikan Fisika dan Teknologi, 2(1), 30-35.

Susilo, J.M. 2006. Gaya Belajar Menjadikan Makin Pintar. Yogyakarta: PINUS.

Suyono \& Hariyanto. 2016. Belajar dan Pembelajaran Teori dan Konsep Dasar. Bandung: PT REMAJA ROSDAKARYA.

Wahyuni, R., Hikmawati, H., \& Taufik, M. 2016. Pengaruh Model Pembelajaran Inkuiri Terbimbing dengan Metode Eksperimen terhadap Hasil Belajar Fisika Siswa Kelas XI IPA SMAN 2 Mataram Tahun Pelajaran 2016/2017. Jurnal Pendidikan Fisika dan Teknologi, 2(4), 164-169.

Yannuansa, N., \& Kusmayadi, T. A. 2015. Eksperimentasi Model Pembelajaran Kooperatif Tipe Tai Dengan Pendekatan Kontekstual Pada Pokok Bahasan Bangun Ruang Sisi Datar Ditinjau Dari Gaya Belajar Siswa Kelas VIII SMP Se-kota Kediri. Jurnal Elektronik Pembelajaran Matematika. 294-304. 